\title{
A Review on Developments in Manufacturing Process and Mechanical Properties of Natural Fiber Composites
}

\author{
Md. Maruf Billah, M S Rabbi , Afnan Hasan
}

Department of Mechanical Engineering, Chittagong University of Engineering \& Technology, Chattogram-4349, Bangladesh

Received: January 02, 2021, Revised: January 22, 2021, Accepted: January 24, 2021, Available Online: February 03,2021

\begin{abstract}
From the last few decades, the study of natural fiber composite materials has been gaining strong attention among researchers, scientists, and engineers. Natural fiber composite materials are becoming good alternatives to conventional materials because of their lightweight, high specific strength, low thermal expansion, eco-friendly, low manufacturing cost, nonabrasive and bio-degradable characteristics. It is proven that natural fiber is a great alternative to synthetic fiber in the sector of automobiles, railway, and aerospace. Researchers are developing various types of natural fiber-reinforced composites by combining different types of natural fiber such as jute, sisal, coir, hemp, abaca, bamboo, sugar can, kenaf, banana, etc. with various polymers such as polypropylene, epoxy resin, etc. as matrix material. Based on the application and required mechanical and thermal properties, numerous natural fiber-based composite manufacturing processes are available such as injection molding, compression molding, resin transfer molding, hand lay-up, filament welding, pultrusion, autoclave molding, additive manufacturing, etc. The aim of the paper is to present the developments of various manufacturing processes of natural fiber-based composites and obtained mechanical properties.
\end{abstract}

Keywords: Natural Fiber Composites, Manufacturing Processes, Mechanical Properties.

This work is licensed under a Creative Commons Attribution-Non Commercial 4.0 International License.

\section{Introduction}

The research field of Natural Fiber Composites (NFC) has been increased due to its higher prospectus and are considering nowadays as the alternatives of carbon or glass fiber composites. Among extensive applicable fields, the demand for NFC, especially in the automotive industry is increasing comprehensively because of sound attenuation capability and lightweight, results in better fuel efficiency. NFC does not only reduce the weight of the vehicle but also lower the cost and energy needed for its production by $80 \%$ [1]. NFC can also be used to fabricate furniture, tiles, and marine piers [2]. However, the natural fiber composites have some distinct disadvantages over glass fiber composites such lower load capability, higher moisture absorption, and lower processing temperature [2],[3].

Between plant and animal fiber, the former one gives more strength and stiffness rather than the later one though silk, a plant fiber is relatively expensive [4]. The cellulose-based natural fiber such as ramie, flax, hemp can give higher mechanical properties than other. The selection of fiber for NFC depends on geography, for example, jute, flax fiber, kenaf, whereas hemp and ramie have more interest in Europe, andin Asia, sisal fiber gets the large interest. The mechanical properties of natural fiber vary with the chemical composition and chemical structure of the fiber, usually related to the fiber harvesting time, growing conditions, storage procedures, extraction method, and the chemical treatment prior to the product fabrication. Mechanical strength may be reduced by $15 \%$ when it is harvested 5 days later of optimum harvesting time [5]. In case of the extraction process, manually extracted fiber can show $20 \%$ higher strength than mechanically extracted [6]. To establish as alternatives of glass fiber, natural fiber should be collected as an optimum way in terms of time and process that can give closer strength to glass fiber.

Apart from the fiber, one of the distinctive constituents of composites is the matrix, used as the binder in the laminate.
Various thermoplastic materials such as polyvinyl chloride (PVC), polypropylene (PP), polyethylene, and polyolefin are being used in NFC [7]. Thermoset polymer materials such as epoxy resin, unsaturated polyester, VE resins, and phenolformaldehyde are used as matrices material as well though on small scale [8],[9]. Thermoset plastic exhibits better physical properties under the operating temperature of $200^{\circ} \mathrm{C}$, the reason makes thermoplastics as matrices material more suitable [9].

Surface modification of fiber by coupling agent and compatibilizer is an important step for producing NFC [10].It enhances the interfacial strength between fiber and matrices. Coupling agent creates strong bond in the interface by reacting with fiber and matrices simultaneously during processing time. Besides, polymeric compatibilizer is interfacial agent which grafts fiber and matrices onto the chain of polymer [11],[12]. The mechanical properties of NFC significantly depend on which coupling agent or compatibilizer is adhered [13],[14].

The manufacturing process plays an important role on the property of NFC [15]-[17]. Fiber lengths, product size, chemical treatment of fiber are the main parameters for selecting the manufacturing process associated with NFC [18]-[20]. Long fiber and large-size products follow open mold manufacturing processes like hand lay-up, automated tape laying, etc. for better mechanical and thermal properties [1],[21]. Relatively complex and small-scale NFC product made from short fiber through closed mold process such as injection molding, compression molding, transfer molding [19],[21]. Exceptionally short fiber is used in spray up open mold processing [22]. Strong fiber dispersion provides better interfacial bonding between fiber and matrices by reducing the void at this interface [23]. For overcoming this reason higher intensive mixing process like single screw extruder and twin-screw extruder are used [24][26].

In this article, the developments in the manufacturing process associated with NFC are reviewed. Conventional 
manufacturing processes for NFCs are discussed in Section 2. Section 3 depicted the comparisons of selected mechanical properties from mentioned processes. Future research work is mentioned in Section 4. Finally conclusions are drawn in Section 5.

\section{Manufacturing Processes}

Earlier, composite materials were produced directly by human hand [27],[28]. With the advancement of technology and increasing demand, it goes through semi-automated to automated processes like additive manufacturing. The closed mold processes are being famous in the current century because of higher precision, accuracy, and productivity [29],[30]. Injection molding, Compression molding, Resin transfer molding are the most commonly used manufacturing method of NFC material in recent days. Hand lay-up, autoclave, Pultruded, Filament wound, etc. are the special method for specific type products manufacturing. The hand lay-up process is substituted by automated tape laying process for its technological benefits [31][33]. In this section of the report, various manufacturing processes of NFCs are upheld with manufactured composite's mechanical properties.

\subsection{Injection Molding}

In injection molding process, a specific amount of fiber and molten polymer is mixed into a mold cavity by sufficient force. Various studies have been done on the injection molding process [34]-[39]. In the injection molding process, both thermosets and thermoplastics polymer are used, but the process included with thermoset is difficult to execute [40],[41]. The process parameter of thermosets such as curing time, curing temperature, injection pressure, and injection torque were investigated by Deringer et al. [42] for epoxy-based natural fiber composite. An schematic setup of injection molding process is given in Fig. 1.

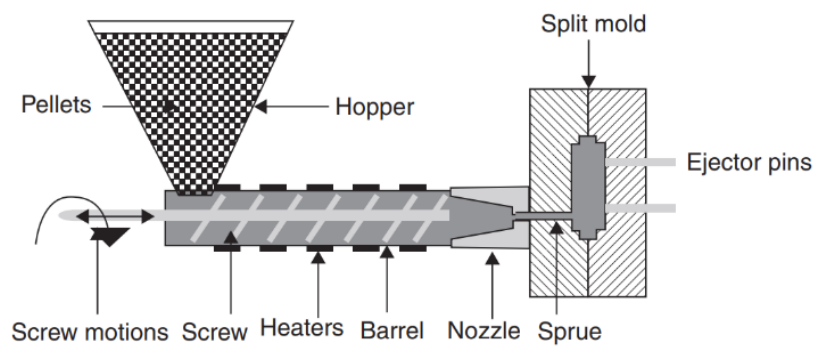

Fig. 1 Schematic setup of injection molding process [43].

In a contrast, thermoplastic polymer-based natural fiber composites production is quite easier in the injection molding process [44]. The small pellets of the thermoplastic polymer are mixed with chopped fiber and feed into a hopper. The material thus passes through high temperature and high-pressure melting section by rotating screw (single screw extruder or twin-screw extruder). High temperature is responsible for melting the material and made it viscous fluid. Finally, it goes through the sprue nozzle into mold cavities due to the above-mentioned high pressure. After solidifying, the product ejects from the mold cavities. The screw-type extruder generates the required share force for the following purpose:

(1) Generates heat to melt the pellets and reduced the friction between barrel, pellet, and screw [39],

(2) Ensures better mixing of polymer matrices and fiber [11],
(3) Push the mixture into the sprue nozzle through the mold cavities with sufficient force [11].

It has been found that the increase of temperature reduced the share viscosity of biodegradable polymers [45].

In the injection molding process, fiber length should be appropriate to transfer entire stress from matrices to fiber and better performance by following the formula [46]:

$$
I_{c}=\frac{\sigma_{f u} d}{2 \tau}
$$

where, $I_{c}, d, \tau$ and $\sigma_{f u}$ are critical fiber length, fiber diameter, shear stress at the interface of fiber and matrix and ultimate tensile strength of fiber respectively.

It is reported that the mechanical property of NFC is maximum at an optimum fiber length. Due to the imperfect interfacial bonding between fiber surface and matrix, the property might not reach its highest value though the critical fiber length has been obtained from equation (1) [11]. Thus, it is mandatory to choose optimum fiber length for the injection molding process. Otherwise, a predetermined critical fiber length may cause fracture in matrices.

Fiber orientation and residual stress in NFC are also important issues for unequal modulus distribution. Improper mixing, insufficient heating after injection may cause irregular fiber orientation and rapid cooling of molten polymer, excessive pressure at the mold section is accountable for growing residual stress [47]. This unexpected residual stress causes tensile stress at external surface of the product and compressive stress at intermediate region which is called injection-molded characteristic residual stress distribution ${ }^{49}$. Various studies have been performed in residual stress development factors [45],[48][50]. It has been found that non-uniform temperature distribution along with whole molten polymer, higher pressure gradient, polymer chain orientation, unequal thermal expansion coefficient between fiber and matrices are major causes of building residual stress in NFC. The geometrical parameters like mold cavities, mold shape, mold size, mold vents which help to escape air babble, and injection gate location are also responsible for stress concentration [11]. On the other hand, non-uniform fiber orientation developed due to unequal thickness of mold which causes variation in properties through the final product. For more fiber concentrated region shows fiber dominating properties and molten polymer generates a complex flow geometry on upstream [51]. Mechanical properties of NFCs which are made by injection molding process from previous literatures are listed in Table 1.

\subsection{Compression Molding}

Compression molding (CM) is the oldest manufacturing process among all of them. Plastic products are produced at a very early stage by $\mathrm{CM}$ process. In the composite manufacturing industry, it achieves huge scopes parallelly for glass fiber and natural fiber [59],[60].Both thermoplastic and thermoset matrix natural fiber composites can be produced by CM [61]. There are two mold sections, upper and lower, in the CM process. The charge is placed at the lower section of mold and during the molding time the upper section press with sufficient pressure and temperature to get the shape inside the mold cavity. The CM process can be called the combination of autoclave and hot press process. Both short and long fiber composite can be produced by this process. Prepregs of thermoplastic material are laid in a 
proper sequence on mold in autoclave process. Then the laminate is bagged in negative pressure and placed inside the autoclave. The laminate goes through heat and pressure cycle and after curing the desired composite is formed [62]. On the other hand, it is not necessary of closed the mold in hot press process [63]. In close mold, precut and measured amount of natural fiber are stacked with each other and placed in the mold cavity (see Fig. 2).

Table 1 Mechanical Properties of NFC prepared by Injection molding process

\begin{tabular}{|c|c|c|c|c|c|c|c|}
\hline Matrices & Fiber & $\begin{array}{c}\text { Fiber } \\
\text { percentage }(\% \\
\text { mass })\end{array}$ & $\begin{array}{l}\text { Tensile } \\
\text { strength } \\
(\mathrm{MPa})\end{array}$ & $\begin{array}{l}\text { Flexural } \\
\text { strength } \\
(\mathrm{MPa})\end{array}$ & $\begin{array}{l}\text { Young's } \\
\text { modulus } \\
(\mathrm{GPa})\end{array}$ & $\begin{array}{c}\text { Flexural } \\
\text { modulus } \\
(\mathrm{GPa})\end{array}$ & Reference \\
\hline $\mathrm{PP}$ & Hemp & 40 & 52 & 86 & 4 & 4 & {$[52]$} \\
\hline PP & Newsprint & 40 & 53 & 94 & 3 & 4 & {$[52]$} \\
\hline PP & Kraft & 40 & 52 & 90 & 3 & 4 & {$[52]$} \\
\hline PP & Flax & 30 & 52 & 60 & 5 & 5 & [53] \\
\hline $\mathrm{PP}^{*}$ & Flax & 30 & - & 70 & - & 6 & [54] \\
\hline PP & Wood BKP & 40 & 50 & 78 & 3 & 3 & [55] \\
\hline PP & Jute & 60 & 74 & 112 & 11 & 12 & {$[56]$} \\
\hline $\mathrm{PA}$ & Cordenka & 30 & 120 & - & 6 & - & [57] \\
\hline PLA & Cordenka & 25 & 108 & - & 4 & - & [58] \\
\hline $\mathrm{PP}$ & Cordenka & 42 & 90 & - & 4 & - & [58] \\
\hline
\end{tabular}

PP = Polypropylene, BKP = Bleached Kraft Pulp, PA = Polyamide, PLA = Polylactide Acid

*High molecular weightmaleic acid anhydride modified PP.

Table 2 Mechanical Properties of NFC prepared by Compression molding process

\begin{tabular}{cccccccc}
\hline Matrices & Fiber & $\begin{array}{c}\text { Fiber } \\
\text { percentage }(\% \\
\text { mass })\end{array}$ & $\begin{array}{c}\text { Tensile } \\
\text { strength } \\
(\mathrm{MPa})\end{array}$ & $\begin{array}{c}\text { Flexural } \\
\text { strength } \\
(\mathrm{MPa})\end{array}$ & $\begin{array}{c}\text { Young's } \\
\text { modulus } \\
(\text { GPa })\end{array}$ & $\begin{array}{c}\text { Flexural } \\
\text { modulus } \\
(\mathrm{GPa})\end{array}$ & Reference \\
\hline PP & Kenaf & 30 & 46 & 58 & 5 & 4 & {$[10]$} \\
UP & PALF & 30 & 53 & 80 & 2 & 3 & {$[65]$} \\
Epoxy & Harakeke & 45 & 136 & 155 & 11 & 10 & {$[66]$} \\
Epoxy & Hemp & 50 & 105 & 126 & 9 & 8 & {$[66]$} \\
Epoxy & Hemp & 65 & 113 & 145 & 18 & 10 & {$[67]$} \\
Epoxy & Hemp & 65 & 165 & 180 & 17 & 9 & {$[67]$} \\
PP & Hemp & 46 & - & 127 & - & 11 & {$[68]$} \\
PLA & Hemp & 30 & 83 & 143 & 11 & 7 & {$[67]$} \\
PLA & Kenaf & 40 & 82 & 126 & 8 & 7 & {$[69]$} \\
PHB & Kenaf & 40 & 70 & 101 & 6 & 7 & {$[69]$} \\
PLA & Hemp & 30 & 77 & 101 & 10 & 7 & {$[69]$} \\
PLA & Kenaf & 80 & 223 & 254 & 23 & 22 & {$[70]$} \\
Epoxy & Sisal & 73 & 410 & 320 & 6 & 27 & {$[71]$} \\
Epoxy & Sisal & 77 & 330 & 290 & 10 & 22 & {$[71]$} \\
Epoxy & Harakeke & 55 & 223 & 223 & 17 & 14 & {$[72]$} \\
Epoxy & Harakeke & 52 & 211 & - & 15 & - & {$[73]$} \\
PLA & Harakeke & 30 & 102 & - & 8 & - & {$[66]$} \\
Epoxy & Flax & 50 & 290 & 248 & 24 & 22 & {$[42]$} \\
Epoxy & Flax & 40 & 34 & 90 & - & - & {$[74]$} \\
Epoxy & Bamboo & 40 & 23 & 58 & - & - & {$[74]$} \\
UP & Flax & 58 & 304 & - & 30 & - & {$[75]$} \\
PP & Flax & 50 & 40 & - & 7 & - & {$[76]$} \\
UP & PALF & 30 & 53 & 80 & 2 & 3 & {$[65]$} \\
PHB & Lyocell & 30 & 66 & 105 & 5 & 5 & {$[69]$} \\
\hline UP & 30 & 56 & & \\
\hline
\end{tabular}

UP = Unsaturated Polyester, PLAF = Pineapple Leaf Fiber, PHB = Poly (3-Hydroxybutyrate). 


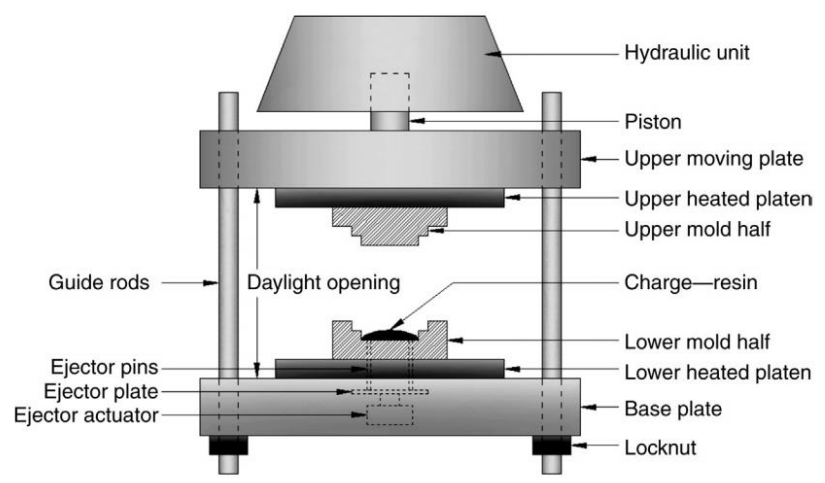

Fig. 2 Schematic setup of compression molding process [64].

In the CM process, BMCs and SMCs are the consecutive initial charge of this molding process. Around 30 to $70 \%$ of the lower mold cavity is filled up by this initial charge [62]. Sufficient pressure is applied before getting high temperature. In that case, some fiber may fracture when excessive pressure is applied before molten of matrices. After applying heat, it gets cool and removed from the mold cavity. Lots of studies had been done to find out the prospects of using renewable polymer and natural fiber composite as a new form of bio-composite by compression molding process [34]-[37]. Zero shear stress, proper placing of fiber in the mold cavity, unwanted motion during processing ensure minimum fiber damage. To make large volume fraction of fiber, long fiber can be used. And for better reinforcement and lower shrinkage of molten material, short fiber and compound should be mixed with each other ${ }^{11}$. Mechanical properties of NFCs which are made by the CM process from previous literatures are listed in Table 2 .

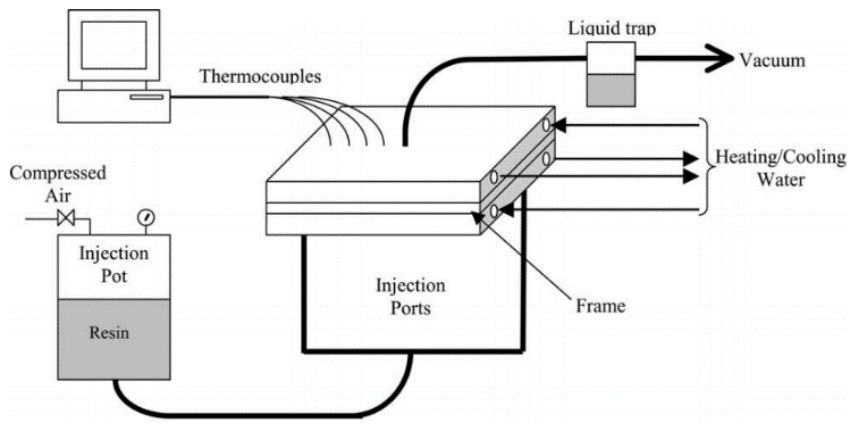

Fig. 3 Schematic setup of resin transfer molding process [84].

\subsection{Resin Transfer Molding}

Table 3.

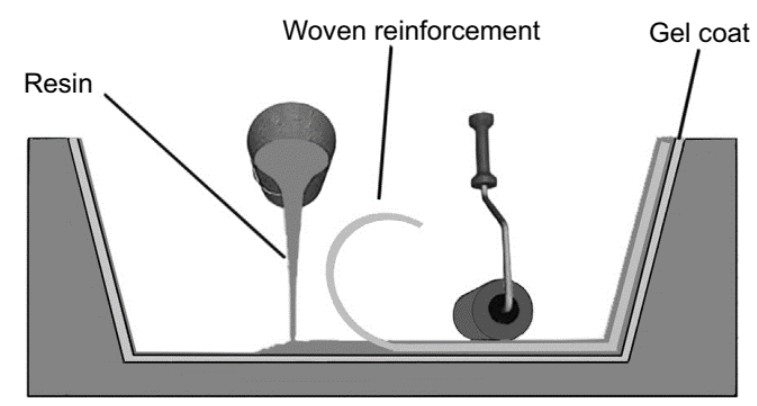

Fig. 4 Schematic setup of hand lay-up process [96].
In resin transfer molding (RTM), thermoset resin is used as matrices which is injected in mold cavity containing fiber (see Fig. 3). To avoid leakage, two halves of matching molds are clamped together with sufficient pressure. Generally, continuous or long fiber is used in the RTM process [30],[77]. Various studies have been done to find out the prospects of resin transfer molding process [29],[78]-[82]. The process parameter of thermosets such as curing time, curing temperature, heat flow, and degree of cure were investigated by Rouison et al. [30] for unsaturated polyester resin-based natural fiber composite. Dominating criteria of RTM are injection pressure, temperature, perform architecture of fiber, resin viscosity, fiber mat permeability, and mold configuration [11]. The main advantages of RTM over the other processes are requirement of lower temperature and abstinence of thermomechanical degradation [83]. Natural fibers have lower compaction than glass fibers which made an effect on the NFC properties of low density in the RTM process [83]. RTM is suitable for large volume production which is also cost-effective compared to other manufacturing processes [11]. Higher injection temperature and pressure reduces the RTM manufacturing cycle time. Though excessive pressure may deform the mold shape and excessive temperature may cause premature resign formation.

In the RTM process, little clearance should be maintained between mold edges and fiber which adjust the fiber perform deformation. At the beginning stage of injection process, higher velocity difference exists which is reduced with respect to the time difference. The flow resistance is accountable for reducing this velocity difference [60]. Without increasing injection pressure, resin flow can be faster by using multiple injection gates. But, a large number of gates creates the process more complex and creates numerous bubbles in the meet point of flow fronts [85]. This void content area reduces the mechanical properties remarkably. To reduce the void in the product, the injection pot and mold need to remain vacuum before starting injection process.

Besides, higher flow resistance creates an obstacle in flow path and flow goes into lower resistance channel for injection pressure hence the effect is escalated. Therefore, the required time at edge flow of bottom is increased which creates adverse effect to format spillage and dry spots [86].The average velocity field of resin flow may look smooth but the local velocity field can be varied point to point at microscopic scale. Local capillary pressure, permeability, non-uniform microstructures are the main reason for local velocity field roughness [87]. Mechanical properties of NFCs which are made by resin transfer molding process from previous literatures are listed in

Mechanical properties of NFCs which are made by resin transfer molding process from previous literatures are listed in Table 4.

\subsection{Hand Lay-up}

Hand lay-up is older open mold manufacturing technic of natural fiber reinforcement composites compared to others [93]. Long and continuous natural, glass or carbon fiber composite materials can be prepared easily by this process for wide range size of products [27]. Hand lay-up has wide variation to orient fiber in different directions such as unidirectional, inclined or woven. Hybrid composites are made step by step in this process that types of composite gains strong attention in composites industry because of its less directional dependency and resistance to multiple types of stress [94]. 
In this process, antiadhesive agent is treated at mold surface to prevent polymer sticking and to release it easily [95]. In bottom and top section of the mold plate, a plastic sheet is placed to get smooth surface [96]. Then gel coat of matrix material is applied to the lower mold surface and the fiber which is in various orientation and chemically treated, is kept immediately on coat as shown in Fig. 4. Then, little amount of pressure is created by roller to removed trapped air bubbles from it. Fiber, matrix or both need to mix with ingredients which ensure stronger interfacial bond on this different material [97]. After fully cured of base material the hardened product is removed from mold cavity [78].

Table 3 Mechanical Properties of NFC prepared by Resin transfer molding process

\begin{tabular}{|c|c|c|c|c|c|c|c|}
\hline Matrices & Fiber & $\begin{array}{c}\text { Fiber } \\
\text { percentage } \\
(\% \text { mass })\end{array}$ & $\begin{array}{l}\text { Tensile } \\
\text { strength } \\
(\mathrm{MPa})\end{array}$ & $\begin{array}{c}\text { Flexural } \\
\text { strength } \\
(\mathrm{MPa})\end{array}$ & $\begin{array}{c}\text { Young's } \\
\text { modulus } \\
(\mathrm{GPa})\end{array}$ & $\begin{array}{c}\text { Flexural } \\
\text { modulus } \\
(\mathrm{GPa})\end{array}$ & Reference \\
\hline UP & Flax & 39 & 61 & 91 & 6 & 5 & {$[88]$} \\
\hline UP & Jute & 35 & 50 & 103 & 8 & 7 & [88] \\
\hline Bio-epoxy & Cellulose & - & 92 & 727 & 9 & 27 & [89] \\
\hline VE & Flax yarn & 35 & 111 & 128 & 10 & 10 & [89] \\
\hline VE & Flax yarn & 24 & 248 & - & 24 & - & [90] \\
\hline UP & Flax yarn & 34 & 143 & 198 & 14 & 17 & [90] \\
\hline Epoxy & Flax & 37 & 132 & - & 15 & - & [91] \\
\hline Epoxy & Flax & 46 & 280 & - & 35 & - & [92] \\
\hline Epoxy & Flax & 54 & 279 & - & 39 & - & [92] \\
\hline Epoxy & Sisal & 48 & 211 & - & 20 & - & [91] \\
\hline Epoxy & Sisal & 37 & 183 & - & 15 & - & [91] \\
\hline
\end{tabular}

VE = Vinyl Ester

Table 4 Mechanical Properties of NFC prepared by Hand lay-up molding process

\begin{tabular}{|c|c|c|c|c|c|c|c|}
\hline Matrices & Fiber & $\begin{array}{c}\text { Fiber } \\
\text { percentage }(\% \\
\text { mass })\end{array}$ & $\begin{array}{l}\text { Tensile } \\
\text { strength } \\
(\mathrm{MPa})\end{array}$ & $\begin{array}{c}\text { Flexural } \\
\text { strength } \\
(\mathrm{MPa})\end{array}$ & $\begin{array}{l}\text { Young's } \\
\text { modulus } \\
(\mathrm{GPa})\end{array}$ & $\begin{array}{c}\text { Flexural } \\
\text { modulus } \\
(\mathrm{GPa})\end{array}$ & Reference \\
\hline Epoxy & Jute & 36 & 102 & 53 & 3.8 & 4 & [98] \\
\hline Polyester & Jute & 20 & 36 & 64 & - & - & [99] \\
\hline Polyester & Jute & 30 & 41 & 71 & - & - & [99] \\
\hline Polyester & Jute & 40 & 46 & 82 & - & - & [99] \\
\hline UP & Jute & 14 & 23 & - & 4 & - & [100] \\
\hline PLA & Bamboo & 40 & 115 & - & 6 & - & [101] \\
\hline UP & Bamboo & 15 & 22 & - & 4 & - & [100] \\
\hline UP & Kenaf & 13 & 28 & - & 5 & - & [100] \\
\hline Epoxy & Banana & 40 & 108 & 72 & - & - & [102] \\
\hline Epoxy & Banana & 50 & 113 & 65 & - & - & [102] \\
\hline Epoxy & Banana & 60 & 98 & 77 & - & - & [102] \\
\hline Epoxy & Banana & - & 37 & 128 & - & - & [103] \\
\hline Epoxy & Coir & 30 & 24 & 25 & 1 & - & [104] \\
\hline Epoxy & Coir & 40 & 21 & 14 & 1 & - & [104] \\
\hline Epoxy & Coir & 50 & 18 & 6 & 2 & - & [104] \\
\hline Polyester & Rattan & 10 & 16 & 48 & - & - & [105] \\
\hline Polyester & Rattan & 18 & 12 & 31 & - & - & [105] \\
\hline Epoxy & Rattan & 13 & 13 & 131 & - & - & [103] \\
\hline Epoxy & Flax & 31 & 160 & 190 & 15 & 15 & [90] \\
\hline
\end{tabular}

\subsection{Other Processes}

Depends on shape of the products, different types of processes are used to produce NFCs. Pultrusion, Filament wounding, Autoclave molding, and Vacuum bag molding are the most popular among the numerous methods.

Pultrusion was developed at the middle of the twentieth century. The pulled fiber is impregnated by formulated resin in this process (see Fig. 5). Hollow cylindrical shape products are 
mostly produced by pultrusion process. During the manufacturing process, the fiber experiencing high tension and thus results in higher production rate and great fiber orientation [106]. The long/continuous fibers are immersed in resin bath and goes through shaping die, here the curing of impregnated resin occurred [107]. Traditionally this process has higher consistency in quality, distribution, impregnation, and alignment of reinforcing fiber [108],[109]. Mechanical properties of NFCs which are made by pultrusion process from previous literatures are listed Table 5 .

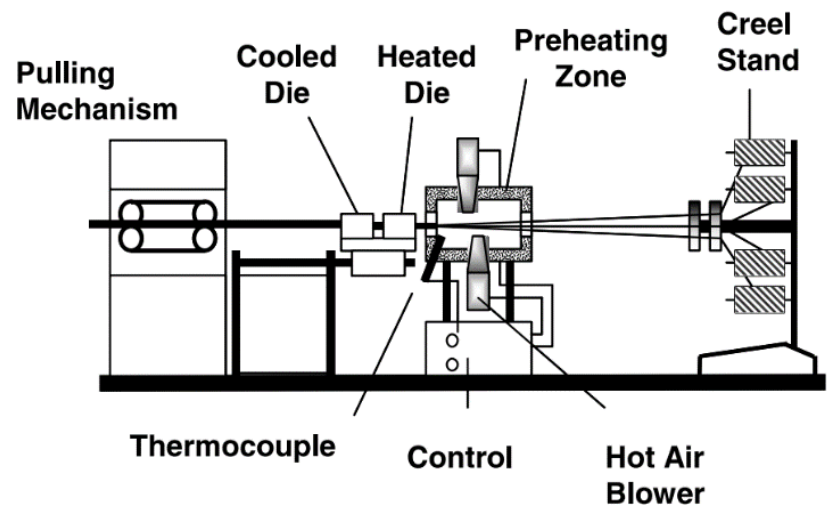

Fig. 5 Schematic setup of pultrusion process [110].

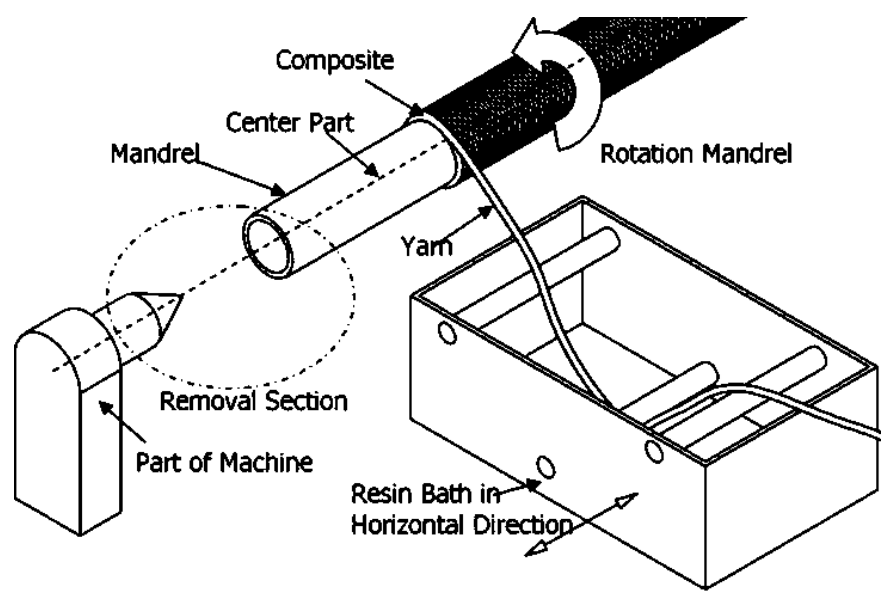

Fig. 6 Schematic setup of filament wounding process [118].

Filament wounding (see Fig. 6) is another open molded manufacturing process which is most preferable for rotationally symmetric products from continuous fiber composites. This process is mostly used for glass and carbon fiber. Recently various study conducted to prove the ability of natural fiber uses too [111]-[116]. Mechanical properties of NFCs which are made by filament wounding process from previous literatures are listed in Table 5. A rotating mandril creats wounding of fiber on it which may be simple or helical. Helical and cross filament wounding provide better mechanical properties compared with simple one [117].

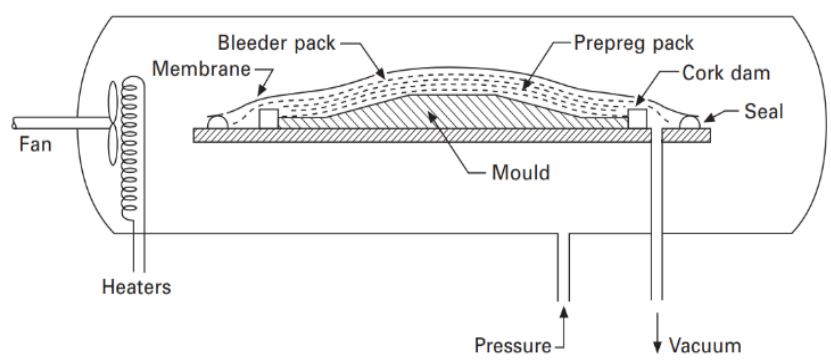

Fig. 7 Schematic setup of autoclave molding process [119].

Autoclave molding ensure higher accuracy and surface finish which is mostly used in aerospace industry from prepregs. A smooth polyester ply covers the both sides of laminates which enhances the surface quality of products (see Fig. 7). A good sealing of whole assembly is provided by non-porous membrane where a porous film covers the top surface of laminate. To remove porosity and volatility of mold, vacuum pressure is crated inside membrane cover where temperature and pressure are controlled to provide exact cure and thermal equilibrium inside the mold. The process is cost intensive and slower compared to other process [119].

Mechanical properties of NFCs which are made by pultrusion, filament wounding, and autoclave molding process from previous literatures are listed in Table 5.

Table 5 Mechanical Properties of NFC

\begin{tabular}{|c|c|c|c|c|c|c|c|c|}
\hline Matrices & Fiber & $\begin{array}{c}\text { Fiber } \\
\text { percentage } \\
(\% \text { mass })\end{array}$ & $\begin{array}{c}\text { Tensile } \\
\text { strength } \\
(\mathrm{MPa})\end{array}$ & $\begin{array}{c}\text { Flexural } \\
\text { strength } \\
(\mathrm{MPa})\end{array}$ & $\begin{array}{l}\text { Young's } \\
\text { modulus } \\
(\mathrm{GPa})\end{array}$ & $\begin{array}{l}\text { Flexural } \\
\text { modulus } \\
(\mathrm{GPa})\end{array}$ & Process & Reference \\
\hline Polyurethane & Hemp & 30 & 122 & 145 & 18 & 12 & Pultrusion & [106] \\
\hline Epoxy & $\begin{array}{c}\text { Flax } \\
\text { hackled }\end{array}$ & 28 & - & 182 & - & 20 & Pultrusion & [90] \\
\hline PP & Flax yarn & 30 & 89 & - & 7 & - & Pultrusion & [110] \\
\hline Epoxy & Flax & 52 & 191 & - & 28 & - & $\begin{array}{l}\text { Filament } \\
\text { wounding }\end{array}$ & [112] \\
\hline EpoBioX & Flax & 48 & 152 & - & 2 & - & $\begin{array}{l}\text { Filament } \\
\text { wounding }\end{array}$ & [112] \\
\hline PP & Flax yarn & 72 & 321 & - & 29 & - & $\begin{array}{l}\text { Filament } \\
\text { wounding }\end{array}$ & {$[120]$} \\
\hline Epoxy & Flax yarn & 45 & 133 & 218 & 28 & 18 & Autoclave & [121] \\
\hline
\end{tabular}




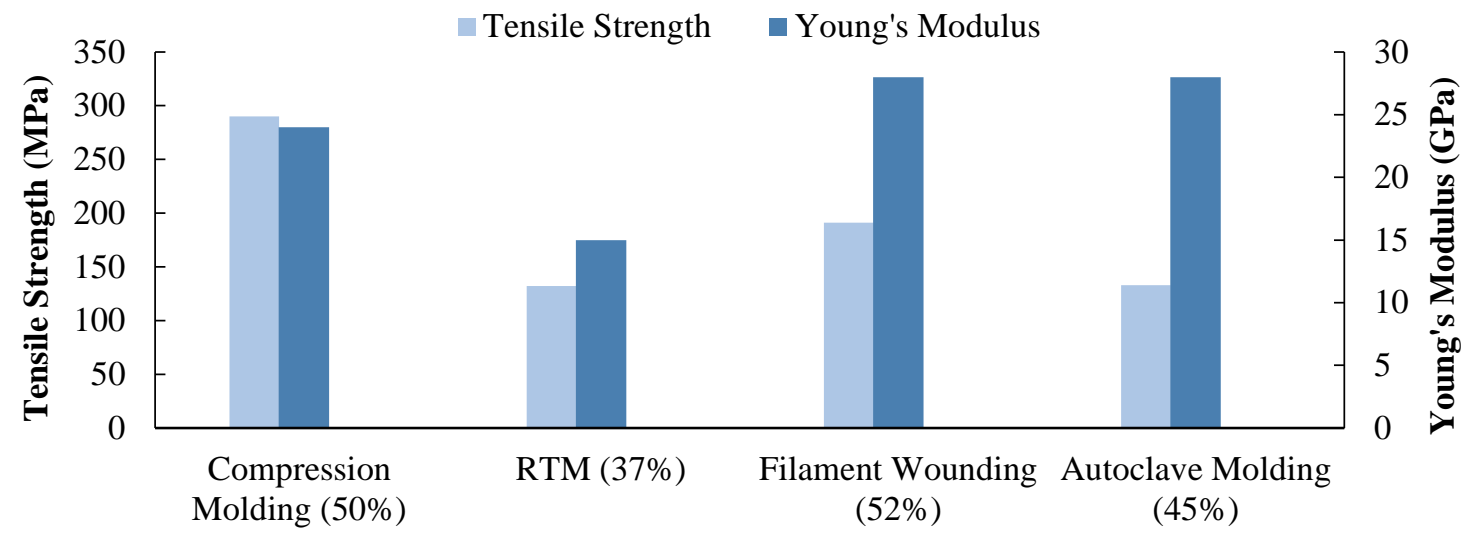

\section{Processes with fiber percentages}

Fig. 8 Comparative Tensile strength and Young's Modulus of epoxy-flax composite from different processes.

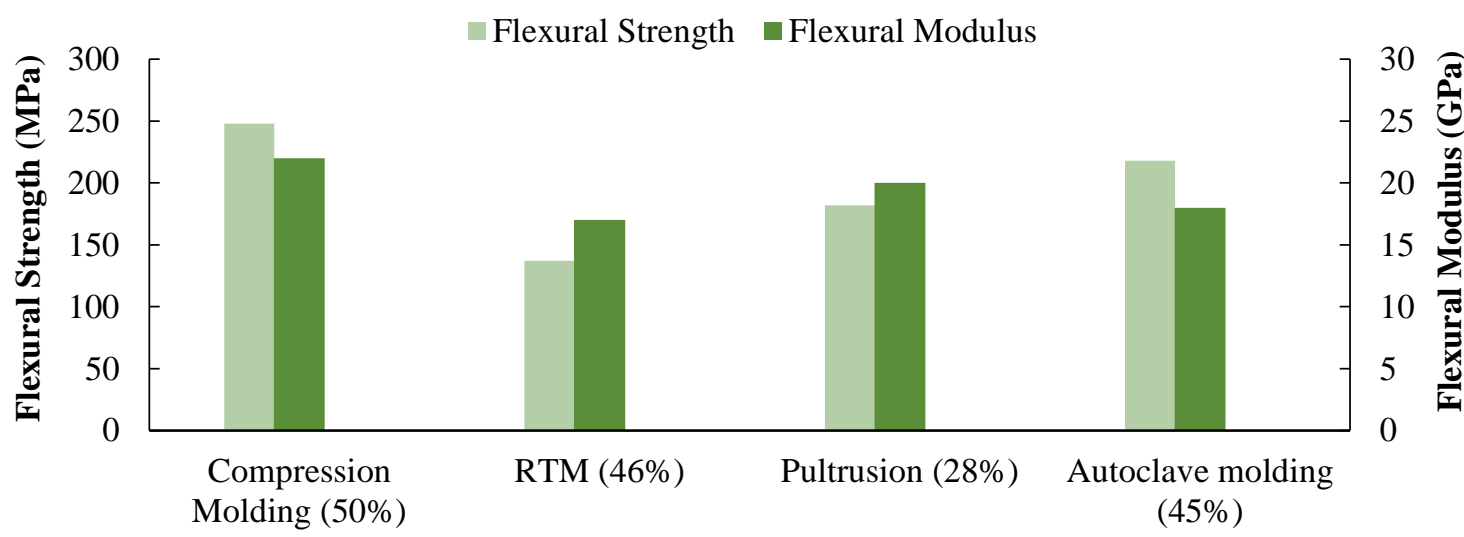

Processes with fiber percentages

Fig. 9 Comparative Flexural strength and Flexural Modulus of Epoxy-Flax composite from different processes.

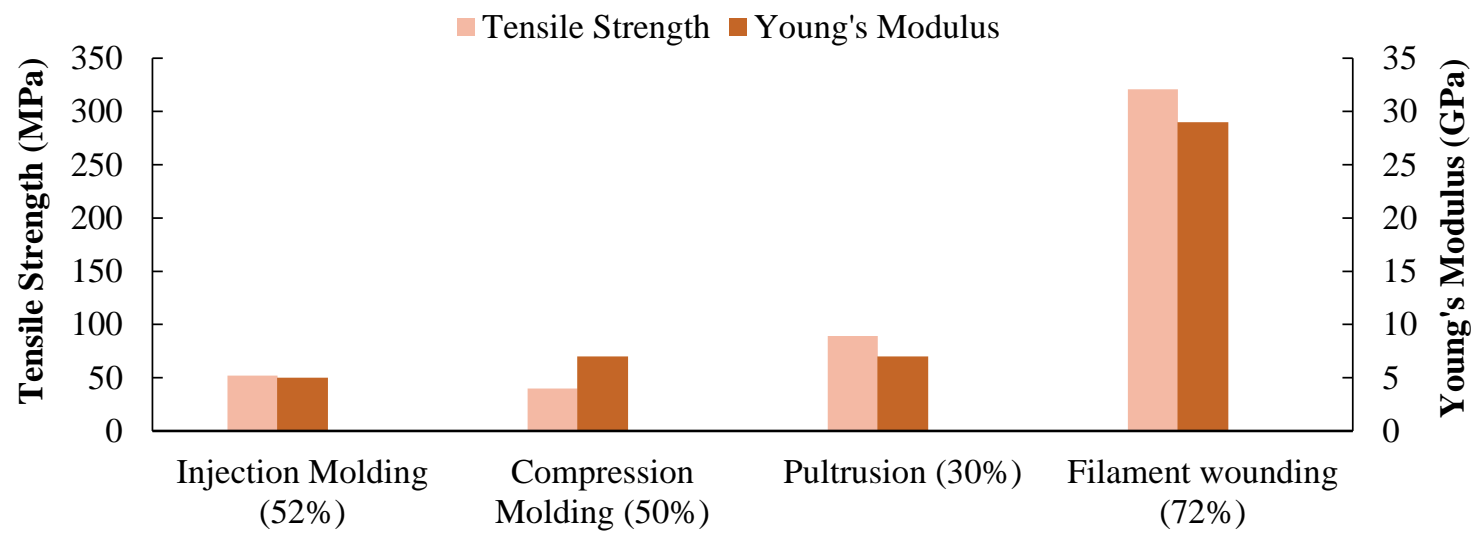

Processes with fiber percentages

Fig. 10 Comparative Tensile strength and Young's Modulus of polypropylene-flax composite from different processes.

\section{Comparisons of Mechanical Properties}

Among all of the discussed natural fiber, flax fiber gives the highest mechanical properties. Consequently, the flax-based NFCs from various processes have more strength compared to others and utmost research has been done associated with it. In this article, adequate mechanical properties of flax-based NFCs with thermoplastics and thermosets binding have been upheld for comparison.

Epoxy as a thermoset has higher mechanical properties but the process associated with it is little complex than thermoplastics. The properties are shown in Fig. 8 and Fig. 9 of epoxy-flax composites with various fiber percentages which are prepared from Compression Molding, Resin Transfer Molding, Filament Wounding, and Autoclave Molding.

Short fiber composites behave like quasi-isotropic material additionally the mechanical properties in a random direction are slightly higher than long fiber composites. Contrastingly, long fiber composites have slightly lower mechanical properties with having strong directional dependency. As a result, compression molding short fiber composite has higher tensile strength than the other three processes. Pure epoxy has tensile strength of 82$115 \mathrm{MPa}$ [122] and flax fiber can show maximum $1500 \mathrm{MPa}$ tensile strength while the minimum is $88 \mathrm{MPa}$ [123]. The fiber percentage can play a tremendous effect where the higher 
strength flax fibers are used. Approximately similar fiber percentages are used in compression molding, filament wounding, and autoclave molding. Among all of them, compression molding gives the highest tensile strength which is $51 \%$ higher than filament wounding. Contrastingly, Young's modulus remains near about similar at every process except Resin transfer molding because of its lower fiber percentage.

Besides, compression molding composite has comparative flexural strength with compared to others except pultrusion process. Though pultrusion process has lower fiber percentage, it shows comparatively higher flexural strength and flexural modulus. Approximately similar fiber percentages are used in compression molding, resin transfer molding and autoclave molding. Among all of them, compression molding gives higher flexural strength which is $13-36 \%$ higher than pultrusion and autoclave molding process.

Polypropylene as a thermoplastic has lower mechanical properties but the process associated with thermoplastics is little easier than thermosets. The properties are shown in Fig. 10 of polypropylene-flax composites with various fiber percentages which are prepared from Injection molding, Compression molding, Pultrusion, and Filament wounding.

The results show similar properties except Filament wounding because of the higher percentage of flax on it. The orientation of fiber in filament wounding is closely packed and orientated rather than compression molding and injection molding. Pultrusion process deal with long fiber which creates directional dependency but gives more strength compared to similar percentages of fiber in compression and injection molding. Pure polypropylene has only tensile strength of $35 \mathrm{MPa}$ [124] and flax fiber can show maximum 1500MPa tensile strength while the minimum is $88 \mathrm{MPa}$ [123]. The fiber percentage can play a tremendous effect on mechanical properties because of the higher properties of flax fiber compared to polypropylene. With increasing 1.5 times of fiber percentages from pultrusion to filament wounding tensile strength increased 2.6 times as well as the tensile modulus.

\section{Future work}

Currently, natural fiber reinforced composites are suffering from lower mechanical strength, lower heat resistance, lower water, and moisture resistance. These properties are strongly dependent on adhesion between matrix and fiber. More the adhesion ensures more mechanical strength, more thermal resistance, more water, and moisture resistance. Suitable manufacturing processes, chemical, and physical treatments of fiber can enhance these properties of NFCs. The above mentioned conventional manufacturing process can give better properties when optimum process parameters and effective physical and chemical treatments of fibers are applied.

\section{Conclusion}

The advancement of natural fiber reinforced composite has become attractive for eco-friendly production. Uses of NFCs have been growing firstly in outdoor and as well as load-bearing applications because of its lightweight and higher specific strength. The manufacturing process associated with it, is developing for suitable and cost-effectiveness. Though it is uncertain to say which process and chemical treatment of fiber are most suitable for a specific product. This article addresses recent developments and issues associated with different natural fiber reinforced composite conventional manufacturing processes. However, researchers are trying to develop economic and effective manufacturing process like additive manufacturing for case dependent simultaneously trying to reduce the production time and to find the most suitable process parameters of individual case. This article addresses recent developments and issues associated with different natural fiber reinforced composite conventional manufacturing processes. Advance composite production is being enriched by injection and compression molding processes where complex geometrical shape can be manufactured with higher mechanical strength compared to others. Rely on this report, it can be remarked that, natural fibers are compatible for reinforcing various polymer for enhancing mechanical properties of it which can be used in wide range of sectors like automotive, housing, packaging, infrastructure etc.

\section{References}

[1] Pickering, K.L., Efendy, M.A. and Le, T.M., 2016. A review of recent developments in natural fibre composites and their mechanical performance. Composites Part A: Applied Science and Manufacturing, 83, pp.98-112.

[2] Malkapuram, R., Kumar, V. and Negi, Y.S., 2009. Recent development in natural fiber reinforced polypropylene composites. Journal of Reinforced Plastics and Composites, 28(10), pp.11691189.

[3] Saheb, D.N. and Jog, J.P., 1999. Natural fiber polymer composites: a review. Advances in Polymer Technology: Journal of the Polymer Processing Institute, 18(4), pp.351-363.

[4] Shah, D.U., Porter, D. and Vollrath, F., 2014. Can silk become an effective reinforcing fibre? A property comparison with flax and glass reinforced composites. Composites Science and Technology, 101, pp.173-183.

[5] Pickering, K.L., Beckermann, G.W., Alam, S.N. and Foreman, N.J., 2007. Optimising industrial hemp fibre for composites. Composites Part A: Applied Science and Manufacturing, 38(2), pp.461-468.

[6] Bos, H.L., Van Den Oever, M.J.A. and Peters, O.C.J.J., 2002. Tensile and compressive properties of flax fibres for natural fibre reinforced composites. Journal of Materials Science, 37(8), pp.1683-1692.

[7] Dos Santos, P.A., Giriolli, J.C., Amarasekera, J. and Moraes, G., 2008 , September. Natural fibers plastic composites for automotive applications. In 8th Annual automotive composites conference and exhibition (ACCE 2008). Troy, MI: SPE Automotive \& Composites Division (pp. 492-500).

[8] Holbery, J. and Houston, D., 2006. Natural-fiber-reinforced polymer composites in automotive applications. Jom, 58(11), pp.80-86.

[9] Summerscales, J., Dissanayake, N.P., Virk, A.S. and Hall, W., 2010. A review of bast fibres and their composites. Part 1-Fibres as reinforcements. Composites Part A: Applied Science and Manufacturing, 41(10), pp.1329-1335.

[10] Zampaloni, M., Pourboghrat, F., Yankovich, S.A., Rodgers, B.N., Moore, J., Drzal, L.T., Mohanty, A.K. and Misra, M., 2007. Kenaf natural fiber reinforced polypropylene composites: A discussion on manufacturing problems and solutions. Composites Part A: Applied Science and Manufacturing, 38(6), pp.1569-1580.

[11] Ho, M.P., Wang, H., Lee, J.H., Ho, C.K., Lau, K.T., Leng, J. and Hui, D., 2012. Critical factors on manufacturing processes of natural fibre composites. Composites Part B: Engineering, 43(8), pp.3549-3562.

[12] Vallejos, M.E., Espinach, F.X., Julian, F., Torres, L., Vilaseca, F. and Mutje, P., 2012. Micromechanics of hemp strands in polypropylene composites. Composites Science and Technology, 72(10), pp.12091213

[13] Matuana, L.M., Balatinecz, J.J., Sodhi, R.N.S. and Park, C.B., 2001 Surface characterization of esterified cellulosic fibers by XPS and FTIR spectroscopy. Wood Science and Technology, 35(3), pp.191201.

[14] Sun, Z.Y., Han, H.S. and Dai, G.C., 2010. Mechanical properties of injection-molded natural fiber-reinforced polypropylene composites: formulation and compounding processes. Journal of Reinforced Plastics and Composites, 29(5), pp.637-650.

[15] Ramesh, M., Palanikumar, K. and Reddy, K.H., 2013. Mechanical property evaluation of sisal-jute-glass fiber reinforced polyester composites. Composites Part B: Engineering, 48, pp.1-9. 
[16] Masoodi, R. and Pillai, K.M., 2011. Modeling the processing of natural fiber composites made using liquid composite molding. Handbook of Bioplastics and Biocomposites Engineering Applications, ed. by S. Pilla, Scrivener-Wiley.

[17] Mohanty, A.K., Wibowo, A., Misra, M. and Drzal, L.T., 2004. Effect of process engineering on the performance of natural fiber reinforced cellulose acetate biocomposites. Composites Part A: applied science and manufacturing, 35(3), pp.363-370.

[18] Drzal, L.T. and Madhukar, M., 1993. Fibre-matrix adhesion and its relationship to composite mechanical properties. Journal of Materials Science, 28(3), pp.569-610.

[19] Pandey, J.K., Ahn, S.H., Lee, C.S., Mohanty, A.K. and Misra, M., 2010. Recent advances in the application of natural fiber based composites. Macromolecular Materials and Engineering, 295(11), pp.975-989.

[20] Medina, L., Schledjewski, R. and Schlarb, A.K., 2009. Process related mechanical properties of press molded natural fiber reinforced polymers. Composites Science and Technology, 69(9), pp.1404-1411.

[21] Elanchezhian, C., Ramnath, B.V., Ramakrishnan, G., Rajendrakumar, M., Naveenkumar, V. and Saravanakumar, M.K., 2018. Review on mechanical properties of natural fiber composites. Materials Today: Proceedings, 5(1), pp.1785-1790.

[22] Cho, D., Seo, J.M., Lee, H.S., Cho, C.W., Han, S.O. and Park, W.H., 2007. Property improvement of natural fiber-reinforced green composites by water treatment. Advanced Composite Materials, 16(4), pp.299-314.

[23] Bongarde, U.S. and Shinde, V.D., 2014. Review on natural fiber reinforcement polymer composites. International Journal of Engineering Science and Innovative Technology, 3(2), pp.431-436.

[24] Feldmann, M., Heim, H.P. and Zarges, J.C., 2016. Influence of the process parameters on the mechanical properties of engineering biocomposites using a twin-screw extruder. Composites Part A: Applied Science and Manufacturing, 83, pp.113-119.

[25] Sui, G., Fuqua, M.A., Ulven, C.A. and Zhong, W.H., 2009. A plant fiber reinforced polymer composite prepared by a twin-screw extruder. Bioresource Technology, 100(3), pp.1246-1251.

[26] Ariffin, A. and Ahmad, M.S.B., 2011. Single screw extruder in particulate filler composite. Polymer-Plastics Technology and Engineering, 50(4), pp.395-403.

[27] Sanjay, M.R. and Yogesha, B., 2017. Studies on natural/glass fiber reinforced polymer hybrid composites: An evolution. Materials Today: Proceedings, 4(2), pp.2739-2747.

[28] Prasad, V., Hunize, C.M., Abhiraj, R.I., Jospeh, M.A., Sekar, K. and Ali, M., 2019. Mechanical properties of flax fiber reinforced composites manufactured using hand layup and compression molding - a comparison. In Advances in Industrial and Production Engineering (pp. 781-789). Springer, Singapore.

[29] Williams, G.I. and Wool, R.P., 2000. Composites from natural fibers and soy oil resins. Applied Composite Materials, 7(5), pp.421-432.

[30] Rouison, D., Sain, M. and Couturier, M., 2003. Resin-transfer molding of natural fiber-reinforced plastic. I. Kinetic study of an unsaturated polyester resin containing an inhibitor and various promoters. Journal of Applied Polymer Science, 89(9), pp.2553-2561.

[31] Haiyan, L., Yong, L., Jun, X. and Dajun, H., 2009. Research on Automatic Tape-laying Technique for Composites-Calculation Method of Tape-laying Path on Free-form Surfaces [J]. Acta Aeronautica Et Astronautica Sinica, 9.

[32] Yao, J., Sun, D., Yao, Z.Q., Zhang, P., Zhang, M.C. and Shi, R.H., 2011. Current situation and research progress of automated tapelaying technology for composites. Ji Xie She Ji Yu Yan Jiu( Machine Design and Research), 27(4), pp.60-65.

[33] Grimshaw, M.N., Grant, C.G. and Diaz, J.M.L., 2001, May. Advanced technology tape laying for affordable manufacturing of large composite structures. In International sampe symposium and exhibition (pp. 2484-2494). SAMPE; 1999.

[34] Serizawa, S., Inoue, K. and Iji, M., 2006. Kenaf-fiber-reinforced poly (lactic acid) used for electronic products. Journal of Applied Polymer Science, 100(1), pp.618-624.

[35] Huda, M.S., Mohanty, A.K., Drzal, L.T., Schut, E. and Misra, M., 2005. "Green" composites from recycled cellulose and poly (lactic acid): physico-mechanical and morphological properties evaluation. Journal of Materials Science, 40(16), pp.4221-4229.

[36] Huda, M.S., Drzal, L.T., Misra, M. and Mohanty, A.K., 2006. Woodfiber-reinforced poly (lactic acid) composites: evaluation of the physicomechanical and morphological properties. Journal of Applied Polymer Science, 102(5), pp.4856-4869.

[37] Huda, M.S., Drzal, L.T., Misra, M., Mohanty, A.K., Williams, K. and Mielewski, D.F., 2005. A study on biocomposites from recycled newspaper fiber and poly (lactic acid). Industrial \& Engineering Chemistry Research, 44(15), pp.5593-5601.

[38] Huda, M.S., Drzal, L.T., Mohanty, A.K. and Misra, M., 2006. Chopped glass and recycled newspaper as reinforcement fibers in injection molded poly (lactic acid)(PLA) composites: a comparative study. Composites Science and Technology, 66(11-12), pp.1813-1824.

[39] Nyström, B., 2007. Natural fiber composites: optimization of microstructure and processing parameters (Doctoral dissertation, Luleå tekniska universitet).

[40] Thomason, J.L. and Rudeiros-Fernández, J.L., 2018. A review of the impact performance of natural fiber thermoplastic composites. Frontiers in Materials, 5, p.60.

[41] Rowell, R.M., 1998. Economic opportunities in natural fiberthermoplastic composites. In Science and Technology of Polymers and Advanced Materials (pp. 869-872). Springer, Boston, MA.

[42] Deringer, T., Gröschel, C. and Drummer, D., 2018. Influence of mold temperature and process time on the degree of cure of epoxy-based materials for thermoset injection molding and prepreg compression molding. Journal of Polymer Engineering, 38(1), pp.73-81.

[43] Leong, Y.W., Thitithanasarn, S., Yamada, K. and Hamada, H., 2014. Compression and injection molding techniques for natural fiber composites. In Natural Fibre Composites (pp. 216-232). Woodhead Publishing.

[44] Farsi, M., 2012. Thermoplastic matrix reinforced with natural fibers: a study on interfacial behavior. Some critical issues for injection molding, pp.225-250.

[45] Fang, Q. and Hanna, M.A., 1999. Rheological properties of amorphous and semicrystalline polylactic acid polymers. Industrial Crops and Products, 10(1), pp.47-53.

[46] Geethamma, V.G., Joseph, R. and Thomas, S., 1995. Short coir fiberreinforced natural rubber composites: effects of fiber length, orientation, and alkali treatment. Journal of Applied Polymer Science, 55(4), pp.583-594.

[47] Santos, J.D., Fajardo, J.I., Cuji, A.R., García, J.A., Garzón, L.E. and López, L.M., 2015. Experimental evaluation and simulation of volumetric shrinkage and warpage on polymeric composite reinforced with short natural fibers. Frontiers of Mechanical Engineering, 10(3), pp.287-293.

[48] Kim, S.K., Lee, S.W. and Youn, J.R., 2002. Measurement of residual stresses in injection molded short fiber composites considering anisotropy and modulus variation. Korea-Australia Rheology Journal, 14(3), pp.107-114.

[49] Lee, K.S., Lee, S.W., Youn, J.R., Kang, T.J. and Chung, K., 2001. Confocal microscopy measurement of the fiber orientation in short fiber reinforced plastics. Fibers and Polymers, 2(1), pp.41-50.

[50] White, J.R., 1985. On the layer removal analysis of residual stress. Journal of Materials Science, 20(7), pp.2377-2387.

[51] Folkes, M.J. and Russell, D.A.M., 1980. Orientation effects during the flow of short-fibre reinforced thermoplastics. Polymer, 21(11), pp.1252-1258.

[52] Sain, M., Suhara, P., Law, S. and Bouilloux, A., 2005. Interface modification and mechanical properties of natural fiber-polyolefin composite products. Journal of Reinforced Plastics and Composites, 24(2), pp.121-130.

[53] Bledzki, A.K., Mamun, A.A., Lucka-Gabor, M. and Gutowski, V.S. 2008. The effects of acetylation on properties of flax fibre and its polypropylene composites. Express Polymer Letters, 2(6), pp.413422.

[54] Snijder, M.H. and Bos, H.L., 2000. Reinforcement of polypropylene by annual plant fibers: optimisation of the coupling agent efficiency. Composite Interfaces, 7(2), pp.69-75.

[55] Li, H. and Sain, M.M., 2003. High stiffness natural fiber-reinforced hybrid polypropylene composites. Polymer-Plastics Technology and Engineering, 42(5), pp.853-862.

[56] Rana, A.K., Mandal, A. and Bandyopadhyay, S., 2003. Short jute fiber reinforced polypropylene composites: effect of compatibiliser, impact modifier and fiber loading. Composites Science and Technology, 63(6), pp.801-806 
[57] Feldmann, M. and Bledzki, A.K., 2014. Bio-based polyamides reinforced with cellulosic fibres-processing and properties. Composites Science and Technology, 100, pp.113-120.

[58] Fink, H.P. and Ganster, J., 2006, December. Novel Thermoplastic Composites from Commodity Polymers and Man-Made Cellulose Fibers. In Macromolecular Symposia (Vol. 244, No. 1, pp. 107-118). Weinheim: WILEY-VCH Verlag.

[59] Adekunle, K., Åkesson, D. and Skrifvars, M., 2010. Biobased composites prepared by compression molding with a novel thermoset resin from soybean oil and a natural-fiber reinforcement. Journal of Applied Polymer Science, 116(3), pp.1759-1765.

[60] Idicula, M., Sreekumar, P.A., Joseph, K. and Thomas, S., 2009. Natural fiber hybrid composites-A comparison between compression molding and resin transfer molding. Polymer Composites, 30(10), pp.1417-1425.

[61] Milanese, A.C., Cioffi, M.O.H. and Voorwald, H.J.C., 2011. Mechanical behavior of natural fiber composites. Procedia Engineering, 10, pp.2022-2027.

[62] Mallick, P.K., 2007. Fiber-reinforced composites: materials, manufacturing, and design. CRC press.

[63] Hu, R. and Lim, J.K., 2007. Fabrication and mechanical properties of completely biodegradable hemp fiber reinforced polylactic acid composites. Journal of Composite Materials, 41(13), pp.1655-1669.

[64] Tatara, R.A., 2017. Compression molding. In Applied plastics engineering handbook (pp. 291-320). William Andrew Publishing.

[65] Devi, L.U., Bhagawan, S.S. and Thomas, S., 1997. Mechanical properties of pineapple leaf fiber-reinforced polyester composites. Journal of Applied Polymer Science, 64(9), pp.1739-1748.

[66] Le, T.M., 2016. Harakeke fibre as reinforcement in epoxy matrix composites and its hybridisation with hemp fibre (Doctoral dissertation, University of Waikato).

[67] Islam, M.S., Pickering, K.L. and Foreman, N.J., 2011. Influence of alkali fiber treatment and fiber processing on the mechanical properties of hemp/epoxy composites. Journal of Applied Polymer Science, 119(6), pp.3696-3707.

[68] Zhang, L. and Miao, M., 2010. Commingled natural fibre/polypropylene wrap spun yarns for structured thermoplastic composites. Composites Science and Technology, 70(1), pp.130-135.

[69] Graupner, N. and Müssig, J., 2011. A comparison of the mechanical characteristics of kenaf and lyocell fibre reinforced poly (lactic acid)(PLA) and poly (3-hydroxybutyrate)(PHB) composites. Composites Part A: Applied Science and Manufacturing, 42(12), pp.2010-2019.

[70] Ochi, S., 2008. Mechanical properties of kenaf fibers and kenaf/PLA composites. Mechanics of Materials, 40(4-5), pp.446-452.

[71] Rong, M.Z., Zhang, M.Q., Liu, Y., Yang, G.C. and Zeng, H.M., 2001. The effect of fiber treatment on the mechanical properties of unidirectional sisal-reinforced epoxy composites. Composites Science and Technology, 61(10), pp.1437-1447.

[72] Le, T.M. and Pickering, K.L., 2015. The potential of harakeke fibre as reinforcement in polymer matrix composites including modelling of long harakeke fibre composite strength. Composites Part A: Applied Science and Manufacturing, 76, pp.44-53.

[73] Newman, R.H., Le Guen, M.J., Battley, M.A. and Carpenter, J.E., 2010. Failure mechanisms in composites reinforced with unidirectional Phormium leaf fibre. Composites Part A: Applied Science and Manufacturing, 41(3), pp.353-359.

[74] Sathish, S., Kumaresan, K., Prabhu, L. and Vigneshkumar, N., 2017. Experimental investigation on volume fraction of mechanical and physical properties of flax and bamboo fibers reinforced hybrid epoxy composites. Polymers and Polymer Composites, 25(3), pp.229-236.

[75] Hughes, M., Carpenter, J. and Hill, C., 2007. Deformation and fracture behaviour of flax fibre reinforced thermosetting polymer matrix composites. Journal of Materials Science, 42(7), pp.2499-2511.

[76] Oksman, K., 2000. Mechanical properties of natural fibre mat reinforced thermoplastic. Applied Composite Materials, 7(5), pp.403414.

[77] Rouison, D., Sain, M. and Couturier, M., 2006. Resin transfer molding of hemp fiber composites: optimization of the process and mechanical properties of the materials. Composites Science and Technology, 66(78), pp.895-906.

[78] Sreekumar, P.A., Joseph, K., Unnikrishnan, G. and Thomas, S., 2007. A comparative study on mechanical properties of sisal-leaf fibrereinforced polyester composites prepared by resin transfer and compression moulding techniques. Composites Science and Technology, 67(3-4), pp.453-461.

[79] Ferland, P., Guittard, D. and Trochu, F., 1996. Concurrent methods for permeability measurement in resin transfer molding. Polymer Composites, 17(1), pp.149-158.

[80] Kim, S.K. and Daniel, I.M., 2003. Determination of three-dimensional permeability of fiber preforms by the inverse parameter estimation technique. Composites Part A: Applied Science and Manufacturing, 34(5), pp.421-429.

[81] Ikegawa, N., Hamada, H. and Maekawa, Z., 1996. Effect of compression process on void behavior in structural resin transfer molding. Polymer Engineering \& Science, 36(7), pp.953-962.

[82] Warrior, N.A., Turner, T.A., Robitaille, F. and Rudd, C.D., 2003. Effect of resin properties and processing parameters on crash energy absorbing composite structures made by RTM. Composites Part A: Applied Science and Manufacturing, 34(6), pp.543-550.

[83] Francucci, G., Rodríguez, E.S. and Vázquez, A., 2012. Experimental study of the compaction response of jute fabrics in liquid composite molding processes. Journal of Composite Materials, 46(2), pp.155167.

[84] Rouison, D., Sain, M. and Couturier, M., 2004. Resin transfer molding of natural fiber reinforced composites: cure simulation. Composites Science and Technology, 64(5), pp.629-644.

[85] Kang, M.K., Jung, J.J. and Lee, W.I., 2000. Analysis of resin transfer moulding process with controlled multiple gates resin injection. Composites Part A: Applied Science and Manufacturing, 31(5), pp.407-422.

[86] Richardson, M.O.W. and Zhang, Z.Y., 2000. Experimental investigation and flow visualisation of the resin transfer mould filling process for non-woven hemp reinforced phenolic composites. Composites Part A: Applied Science and Manufacturing, 31(12), pp.1303-1310

[87] Rodriguez, E., Giacomelli, F. and Vazquez, A., 2004. Permeabilityporosity relationship in RTM for different fiberglass and natural reinforcements. Journal of Composite Materials, 38(3), pp.259-268.

[88] Rodríguez, E., Petrucci, R., Puglia, D., Kenny, J.M. and Vazquez, A., 2005. Characterization of composites based on natural and glass fibers obtained by vacuum infusion. Journal of Composite Materials, 39(3), pp.265-282.

[89] Felline, F., Pappada, S., Gennaro, R. and Passaro, A., 2013. Resin transfer moulding of composite panels with bio-based resins. SAMPE Journal, 49(3), pp.20-24.

[90] Goutianos, S., Peijs, T., Nystrom, B. and Skrifvars, M., 2006. Development of flax fibre based textile reinforcements for composite applications. Applied Composite Materials, 13(4), pp.199-215.

[91] Oksman, K., Wallström, L., Berglund, L.A. and Filho, R.D.T., 2002. Morphology and mechanical properties of unidirectional sisal-epoxy composites. Journal of Applied Polymer Science, 84(13), pp.23582365.

[92] Oksman, K., 2001. High quality flax fibre composites manufactured by the resin transfer moulding process. Journal of Reinforced Plastics and Composites, 20(7), pp.621-627.

[93] Davidovits, J., 2015. Geopolymer Chemistry and Applications. 4-th edition. J. Davidovits.-Saint-Quentin, France.

[94] Noorunnisa Khanam, P., Mohan Reddy, M., Raghu, K., John, K. and Venkata Naidu, S., 2007. Tensile, flexural and compressive properties of sisal/silk hybrid composites. Journal of Reinforced Plastics and Composites, 26(10), pp.1065-1070

[95] Kornmann, X., Rees, M., Thomann, Y., Necola, A., Barbezat, M. and Thomann, R., 2005. Epoxy-layered silicate nanocomposites as matrix in glass fibre-reinforced composites. Composites Science and Technology, 65(14), pp.2259-2268.

[96] Raji, M., Abdellaoui, H., Essabir, H., Kakou, C.A. and Bouhfid, R., 2019. Prediction of the cyclic durability of woven-hybrid composites. In Durability and Life Prediction in Biocomposites, Fibre-Reinforced Composites and Hybrid Composites (pp. 27-62). Woodhead Publishing.

[97] Li, X., Tabil, L.G. and Panigrahi, S., 2007. Chemical treatments of natural fiber for use in natural fiber-reinforced composites: a review. Journal of Polymers and the Environment, 15(1), pp.25-33.

[98] Mishra, V. and Biswas, S., 2013. Physical and mechanical properties of bi-directional jute fiber epoxy composites. Procedia Engineering, 51, pp.561-566. 
[99] Bindal, A., Singh, S., Batra, N.K. and Khanna, R., 2013. Development of glass/jute fibers reinforced polyester composite. Indian Journal of Materials Science, 2013.

[100] Hojo, T., Xu, Z., Yang, Y. and Hamada, H., 2014. Tensile properties of bamboo, jute and kenaf mat-reinforced composite. Energy Procedia, 56, pp.72-79.

[101] Sukmawan, R., Takagi, H. and Nakagaito, A.N., 2016. Strength evaluation of cross-ply green composite laminates reinforced by bamboo fiber. Composites Part B: Engineering, 84, pp.9-16.

[102] Ramesh, M., Atreya, T.S.A., Aswin, U.S., Eashwar, H. and Deepa, C., 2014. Processing and mechanical property evaluation of banana fiber reinforced polymer composites. Procedia Engineering, 97, pp.563572.

[103] Islam, M.S., Azmy, S. and Almamun, A., 2019. Comparative study on mechanical properties of banana and rattan fiber reinforced epoxy composites. American Journal of Engineering Research (AJER), 8(2), pp.1-6.

[104] Obele, C. and Ishidi, E., 2015. Mechanical properties of coir fiber reinforced Epoxy resin composites for helmet shell. Industrial Engineering Letters, 5(7).

[105] Rachchh, N.V., Ujeniya, P.A. and Misra, R.K., 2014. Mechanical characterisation of rattan fibre polyester composite. Procedia Materials Science, 6, pp.1396-1404.

[106] Peng, X., Fan, M., Hartley, J. and Al-Zubaidy, M., 2012. Properties of natural fiber composites made by pultrusion process. Journal of Composite Materials, 46(2), pp.237-246.

[107] Nguyen-Chung, T., Friedrich, K. and Mennig, G., 2007. Processability of pultrusion using natural fiber and thermoplastic matrix. Research Letters in Materials Science, 2007.

[108] Van de Velde, K. and Kiekens, P., 2001. Thermoplastic pultrusion of natural fibre reinforced composites. Composite structures, 54(2-3), pp.355-360.

[109] Akil, H.M., Cheng, L.W., Ishak, Z.M., Bakar, A.A. and Abd Rahman, M.A., 2009. Water absorption study on pultruded jute fibre reinforced unsaturated polyester composites. Composites Science and Technology, 69(11-12), pp.1942-1948.

[110] Angelov, I., Wiedmer, S., Evstatiev, M., Friedrich, K. and Mennig, G., 2007. Pultrusion of a flax/polypropylene yarn. Composites Part A: Applied Science and Manufacturing, 38(5), pp.1431-1438.

[111] Bobba, S., Leman, Z., Zainudin, E.S. and Sapuan, S.M., 2020, October. Characterisation of the tensile and fracture properties of filament wound natural fibre rings. In AIP Conference Proceedings (Vol. 2284, No. 1, p. 020015). AIP Publishing LLC.

[112] Lehtiniemi, P., Dufva, K., Berg, T., Skrifvars, M. and Järvelä, P., 2011. Natural fiber-based reinforcements in epoxy composites processed by filament winding. Journal of Reinforced Plastics and Composites, 30(23), pp.1947-1955.

[113] Goutianos, S., Peijs, T., Nystrom, B. and Skrifvars, M., 2007. Textile reinforcements based on aligned flax fibres for structural composites. Composites Innovation.

[114] Gassan, J. and Bledzki, A.K., 1999. Possibilities for improving the mechanical properties of jute/epoxy composites by alkali treatment of fibres. Composites Science and Technology, 59(9), pp.1303-1309.

[115] Lee, S.M. ed., 1992. Handbook of composite reinforcements. John Wiley \& Sons.

[116] Gohil, P.P. and Shaikh, A.A., 2010. Experimental investigation and micro mechanics assessment for longitudinal elastic modulus in unidirectional cotton-polyester composites. International Journal of Engineering and Technology, 2(2), pp.111-118.

[117] Munro, M., 1988. Review of manufacturing of fiber composite components by filament winding. Polymer Composites, 9(5), pp.352359.

[118] Salit, M.S., Jawaid, M., Yusoff, N.B. and Hoque, M.E. eds., 2015. Manufacturing of natural fibre reinforced polymer composites (pp. 1383). New York, USA: Springer International Publishing.

[119] Halley, P.J., 2012. Rheology of thermosets: the use of chemorheology to characterise and model thermoset flow behaviour. In Thermosets (pp. 92-117). Woodhead Publishing.

[120] Madsen, B. and Lilholt, H., 2003. Physical and mechanical properties of unidirectional plant fibre composites-an evaluation of the influence of porosity. Composites Science and Technology, 63(9), pp.1265-1272.

[121] Van de Weyenberg, I., Ivens, J., De Coster, A., Kino, B., Baetens, E. and Verpoest, I., 2003. Influence of processing and chemical treatment of flax fibres on their composites. Composites Science and Technology, 63(9), pp.1241-1246.

[122] Yang, J.P., Chen, Z.K., Yang, G., Fu, S.Y. and Ye, L., 2008. Simultaneous improvements in the cryogenic tensile strength, ductility and impact strength of epoxy resins by a hyperbranched polymer. Polymer, 49(13-14), pp.3168-3175.

[123] Jawaid, M.H.P.S. and Khalil, H.A., 2011. Cellulosic/synthetic fibre reinforced polymer hybrid composites: A review. Carbohydrate polymers, 86(1), pp.1-18.

[124] Arib, R.M.N., Sapuan, S.M., Ahmad, M.M.H.M., Paridah, M.T. and Zaman, H.K., 2006. Mechanical properties of pineapple leaf fibre reinforced polypropylene composites. Materials \& Design, 27(5), pp.391-396. 